\title{
Tuberculosis Treatment Defaulter Survey on Koje Island
}

\author{
Seung Hum Yu, M.D., M.P.H., \\ Dept. of Preventive Medicine and Public Health, Yonsei Univ. College of Medicine
}

John R. Sibley, M.D.

Koje Community Health and Development Project

George Cauthen

Peace Corps Volunteer of the United State

\section{巨濟島에서 結核 治療 中斷者에 對한 調査}
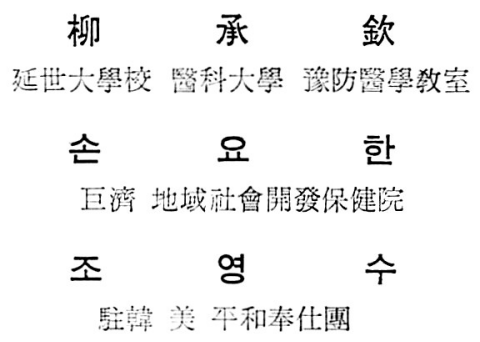

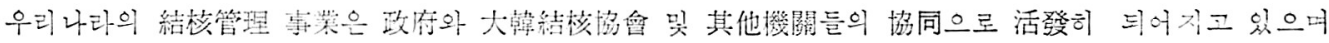
이를 鶏하여 臨床的인 또는 基琵醫學的인 砸究가 多大하였다.

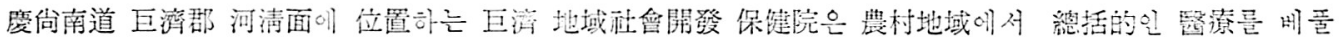

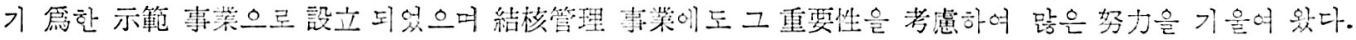

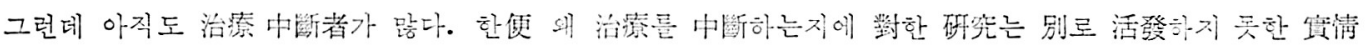
이다.

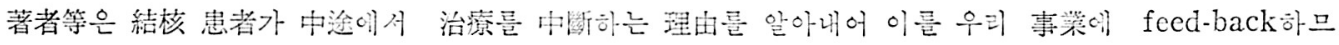
로서 보다 効果的인 結核管理를 꾀하려고 이 研究를 施圖하였다. 對照群으로는 同一 地域阿데서 保健所 登錄者中 治療를 中斷한 患者를 擇하였다.

結果에서 보면 登錄된 患者의 노 以上이 適切한 治療를 밭지 못하였다. 患者를 對하는 泠情한 態度나, 結核에 關한 敉育의 不充分 등으로 結核에 對한 患者들의 知識이 適當하지 못하였다고 셩각할 수 있다. 即 結核을 무서워는 하지만 結核에 關하여 잘 못 알고 있거나 또는 모르고 있으며 特히 一定 期間 繼續 治療하면 大部分 完治된다는 것을 잘 모르고 있다. 그리고 經濟的인 面에서 볼 때 患者들도 治㙩를 爲한 支拂能力이 있었다.

그러므로 著者等은 보카 나은 結核管理를 爲하여 住民이나 患者에계 充分한 教育을 시키는 것이 必要 하다고 본다.

아율러 患者들이 治療를 中斷하는 理由를 알아내고 이를 다시 結核 管理 事業에 反影시키기 篇한 研 ·究가 이루어져야 겠다크 생각한다.

한 便 現在 保揵所를 通하어 供給되는 藥品이 古分하지 못한 것은 事實이지만, 患者도 自己 病의 治 療를 爲하여 어느 程度 治療费를 支拂한 수 있는 바, 不足한 部分은 患者 스스로가 補充하여 治療한다 면 所期의 咸界를 거둘 수 있겠다. 


\section{Intreduction}

Tuberculosis control is one of Korea's most urgent health needs. According to the Ministry of Health and Social Affairs' 1970 prevalence survey, $4.1 \%$ of the population aged 5 years and above has active pulmonary tuberculosis. ${ }^{(1)}$ The government, supported by the Korean $\mathrm{Na}$ tional Tuberculosis Association and other voluntary agencies, has a national program for tuberculosis active case detection and domiciliary treatment for infectious cases. However, it is estimated that only $15 \%$ of the known cases complete the prescribed course of treatment. ${ }^{(1)}$

Moreover, the experience of the Koje Community Health Project was not significantly better, where only $25 \%$ of the optimum number of return appointment for tuberculosis treatment were kept. ${ }^{(2)}$ Therefore, this study was conducted in an attempt to define the reasons most tuberculosis patients failed to complete the course of therapy.

The government health center in Koje Island, like most Korean rural health centers, has a tuberculosis treatment program following the official guidelines of the Ministry of Health and Social Affairs ${ }^{(3)}$. Case detection among the 113,000 people of Koje Island is through sputum collection by the tuberculosis health workers assigned to every myun (or township of about 10,000 population). AFB staining and microscopy is done at the health center where direct and indirect $\mathrm{X}$-ray facilities are also available. However, only about $30 \mathrm{X}$-rays are taken a week. Treatment with free INH, PAS and Streptomycin if indicated is given free to infectious cases or advanced cases of active. pulmonary tuberculosis.

The Koje Community Health Project is a voluntary agency sponsored by the Christian Medical Commission of the World Council of Churches $^{(4)}$ and is attempting to provide comprehensive medical care to about 30,000 residents of the northern $1 / 4$ of the island ( 3 of 10 townships). Case detection has been primarily among self-presenting outpatients at the clinic, where during 1971 tuberculosis of the respiratory system was the fifth most common diagnosis, according for $5 \%$ of the outpatient clinic cases. ${ }^{(2)}$ Direct X-ray is almost the exclusive means. of diagnosing the patient. Treatment, primarily with INH, PAS, or Streptomycin if indicated, sold at a little less than drugstore prices to all cases.

\section{Method}

The tuberculosis treatment defaulters from July 1970 to September 1971 living in the northern $1 / 2$ of the island ( 4 townships and 1 town) were chosen from the tuberculosis registry lists of the Government Health Center and of the Community Health Project. Table 1 shows the outcome of the survey attempt. There were two attempts made to contact every subject,

Table 1. Outcome of Survery Attempt among Tuberculosis Treatment Defaalters.

\begin{tabular}{|c|c|c|c|c|c|c|}
\hline \multirow[b]{2}{*}{ Defaulters Identified } & \multicolumn{2}{|c|}{ Total } & \multirow{2}{*}{$\frac{\text { Koje }}{218}$} & \multirow{2}{*}{$\begin{array}{r}\text { Project } \\
(\%) \\
100\end{array}$} & \multirow{2}{*}{$\begin{array}{r}\text { Health } \\
\begin{array}{c}(\neq) \\
516\end{array}\end{array}$} & \multirow{2}{*}{$\begin{array}{c}\text { Center } \\
(\%) \\
100\end{array}$} \\
\hline & $\begin{array}{r}(\neq \\
734\end{array}$ & $\begin{array}{c}(\%) \\
100\end{array}$ & & & & \\
\hline Interviewed & 278 & 38 & 96 & 44 & 182 & 35 \\
\hline Refused Interview & 4 & + & - & - & 4 & 1 \\
\hline Error of Diagnosis & 29 & 4 & 8 & 4 & 21 & 4 \\
\hline Died & 41 & 6 & 5 & 2 & 36 & 7 \\
\hline Not at Home & 174 & 23 & ? & & ? & \\
\hline Moved or Address in Error & 208 & 29 & ? & 50 & ? & 53 \\
\hline
\end{tabular}

? Separate figures are not available. 
initially during the period October 1 to November 3 and repeated during November 8 to 13, 1971. The high rate of those moved or not at home is thought to be in part due to local custom of temporarily moving to the mainland for treatment of severe illnesses.

\section{Result and Discussion}

\section{Age, sex and occupation}

About 70\% of interviewees (both Koje Project and Health Center) were between 15 and 54, the age range of high productivity.

Among the project-registered defaulters, the number of males is roughly the same as females. However, among the Health Center-registered defaulters males are more than three times as many as females. According to other reports ${ }^{(5,6,7)}$ male registered patients at Health Centers are twice as numerous as females. (Table 2)

About $65 \%$ of defaulters of both institution were from farming and fishing households. Around $15 \%$ of defaulters' households were non- occupied. Among the Health Center-registered, there are more farmers. Since, generally speaking, fishermen are more well-to-do than farmers, and it is probable that a higher proportion of the well-to-do are registered at the Koje project. A study of the Project(11) in 1969 shows that the baseline proportion in the home township of farming and fishing houscholds is $80 \%$.

Table 3. Occupation of Head of Hiousehold

\begin{tabular}{l|c|c}
\hline \multicolumn{1}{c|}{ Occupation } & Koje Project \\
$(\%)$ & $\begin{array}{c}\text { Health Cen- } \\
\text { er (\%) }\end{array}$ \\
\hline Farmer & 24 & 56 \\
Fisherman & 33 & 11 \\
Farmer \& Fisherman & 8 & - \\
Merchant & 3 & 8 \\
Government Officer & 3 & 2 \\
Salaryman & 3 & 2 \\
Non-occupied & 15 & 17 \\
Other and No & 10 & 4 \\
\hline$\quad$ Response & $\mathbf{9 6}$ & $\mathbf{1 8 2}$ \\
\hline No. of People & & \\
\hline
\end{tabular}

*Those under the age of 14 were interviewed with their mothers.

Table 2. Distribution of Defaulters by Age, Sex and Myun

Koje Project

\begin{tabular}{|c|c|c|c|c|c|c|c|c|}
\hline \multirow{2}{*}{ Age } & \multicolumn{5}{|c|}{ Myun } & \multicolumn{3}{|c|}{ Sex } \\
\hline & $\begin{array}{l}\text { Hachung } \\
(\%)\end{array}$ & $\begin{array}{c}\text { Yoncho } \\
(\%)\end{array}$ & $\begin{array}{c}\text { Changmok } \\
(\%)\end{array}$ & $\begin{array}{c}\text { Shinhyun } \\
(\%)\end{array}$ & $\begin{array}{l}\text { Changse- } \\
\text { ungpo }(\%)\end{array}$ & $\stackrel{M}{(\%)}$ & $\begin{array}{c}F \\
(\%)\end{array}$ & $\begin{array}{c}\text { Total } \\
(\%)\end{array}$ \\
\hline $0-4$ & & 11 & & & & 4 & & 2 \\
\hline $5-14$ & 15 & 11 & 22 & & 23 & 12 & 22 & 17 \\
\hline $15-34$ & 39 & 26 & 39 & 25 & 18 & 32 & 30 & 31 \\
\hline $35-54$ & 27 & 31 & 28 & 50 & 55 & 36 & 35 & 35 \\
\hline $55+$ & 18 & 21 & 11 & 25 & 5 & 16 & 13 & 15 \\
\hline No.of People & 33 & 19 & 18 & 4 & 22 & 50 & 46 & 96 \\
\hline
\end{tabular}

Health Center

\begin{tabular}{c|c|c|c|c|c|c|c|c}
$0-4$ & & & & & & & & 10 \\
$5-14$ & 10 & 22 & & 13 & 5 & 11 & $\mathbf{1 0}$ \\
$15-34$ & 45 & 24 & 40 & 20 & 35 & 31 & 33 & $\mathbf{3 2}$ \\
$35-54$ & 28 & 44 & 46 & 35 & 43 & 41 & 36 & $\mathbf{4 0}$ \\
$55+$ & 17 & 10 & 14 & 33 & 16 & 17 & 21 & $\mathbf{1 8}$ \\
\hline No.of People & $\mathbf{2 9}$ & $\mathbf{4 1}$ & $\mathbf{3 5}$ & $\mathbf{4 0}$ & $\mathbf{3 7}$ & $\mathbf{1 4 0}$ & $\mathbf{4 2}$ & $\mathbf{1 8 2}$ \\
\hline
\end{tabular}


결핵 및 호흡기질환 Vol. 19, No. 4, Oct. 1972

Whether the defaulters continue treatment or not.

If the registered patient was over one week or more late for his drug pick-up appointment and had not returned by the date of the survey, he was counted a defaulter. However, some of them went to other clinics, mainly on the mainland, or bought from drug stores. Therefore, defaulters at any one institution may or may not be an actual defaulter.

whether the defaulters continued treatment elsewhere was asked. It was revealed that half of Koje Project-registered defaulters continued treatment elsewhere (male $54 \%$, female $46 \%$ ), while the Health Center-registered defaulters continued at a $40 \%$ rate among males and only $12 \%$ among females. According to the 1971 out patient clinic data report of the Project(2), patients keep 25\% of optimum return appointment for Tuberculosisis treatment. It was reported that $37 \%$ completed treatment with satisfactory results at private tuberculosis clinic. ${ }^{(8)}$
There is a statistically significant difference between sex and "defaulted" by institution (Chi-square, $\mathrm{P}$, less than 0.025).

The Koje Project has the lowest defaulter rate in its home township of Hachung (30\%) and the rate for the Health Center is lowest in its home township of Shinhyun (43\%). Thus it might be interpreted that accessability of the institution plays a role in obtaining treatment continuously.

\section{Defaulting reasons}

Why patients quit treatment is the main question in tuberculosis control. Koje Project defaulters' reasons are "too expensive", "other reason and no response" and "treating elsewhere" in sequence. Health Center defaulters said "other reason and no response", "drugs no longer given at Health Center", "recovered" and "treating elsewhere" in sequence. The Project is non-profit, but charges the patient, even though there is a discount systm.

Table 4. Whether the Defaulaters Continue Treatment or Not by Sex.

\begin{tabular}{|c|c|c|c|c|c|c|c|c|}
\hline & \multicolumn{4}{|c|}{ Koje Project } & \multicolumn{4}{|c|}{ Health Center } \\
\hline & \multirow{2}{*}{$\begin{array}{l}\text { No. of } \\
\text { People }\end{array}$} & \multicolumn{3}{|c|}{ Sex } & \multirow{2}{*}{$\begin{array}{l}\text { No. of } \\
\text { people }\end{array}$} & \multicolumn{3}{|c|}{ Sex } \\
\hline & & $M(\%)$ & $F(\%)$ & $|\operatorname{Total}(\%)|$ & & $M(\%)$ & $F(\%)$ & Total $(\%)$ \\
\hline Defaulted & 45 & 42 & 52 & 47 & 93 & 45 & 72 & 51 \\
\hline Continue & 48 & 54 & 46 & 50 & 61 & 40 & 12 & 33 \\
\hline Recovered & 1 & 2 & & 1 & 21 & 11 & 14 & 12 \\
\hline No Response & 2 & 2 & 2 & 2 & 7 & 4 & 2 & 4 \\
\hline
\end{tabular}

Table 5. Whether the Defaulters Continue Treatment or Not by Myun

\begin{tabular}{|c|c|c|c|c|c|c|c|c|c|c|c|c|}
\hline & \multicolumn{6}{|c|}{ Koje Project } & \multicolumn{6}{|c|}{ Koje Project } \\
\hline & $\left|\begin{array}{c}\text { Hach- } \\
\text { ung } \\
(\%)\end{array}\right|$ & $\begin{array}{l}\text { Yon- } \\
\text { cho } \\
(\%)\end{array}$ & $\begin{array}{l}\text { Cha- } \\
\text { ng: } \\
\text { mok } \\
(\%)\end{array}$ & $\begin{array}{l}\text { Shin- } \\
\text { hyun } \\
(\%)\end{array}$ & $\left|\begin{array}{c}\text { Cha- } \\
\text { ng se- } \\
\text { ungpo } \\
(\%)\end{array}\right|$ & $\begin{array}{c}\text { Total } \\
(\%)\end{array}$ & $\begin{array}{l}\text { Hach } \\
\text { ung } \\
(\%)\end{array}$ & $\begin{array}{c}\text { Yon- } \\
\text { cho } \\
(\%)\end{array}$ & $\begin{array}{l}\text { Cha- } \\
\text { ng- } \\
\text { mok } \\
(\%) \\
\end{array}$ & \begin{tabular}{|l} 
Shin. \\
hyun \\
$(\%)$
\end{tabular} & $\mid \begin{array}{c}\text { Cha- } \\
\text { ngse- } \\
\text { ungpo } \\
(\%)\end{array}$ & $\begin{array}{c}\text { Total } \\
(\%)\end{array}$ \\
\hline Defaulted & 30 & 58 & 50 & 7 & 55 & 47 & 48 & 59 & 49 & 4 & 57 & 51 \\
\hline Continue & 70 & 32 & 50 & 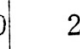 & 41 & 5 & 14 & 26 & 40 & 4 & 35 & 33 \\
\hline No Response & & 5 & & & 5 & 2 & 2 & 7 & & & 5 & 4 \\
\hline Recovered* & & 5 & & & & 1 & 34 & 7 & 11 & & 5 & 12 \\
\hline No. of People & 33 & 19 & 18 & & 22 & 9 & $2 s$ & 41 & 35 & 4 & 37 & 182 \\
\hline
\end{tabular}

*Sometimes patients say thay thay are recovered without confirmed diagnosis if symptoms are not significant. 
결핵 및 호홉기길환 Vol. 19, No. 4, Oet. 1972

Therefore it is natural that proportionally more Project defaulters say "too expensive". Health Centers distribute medicine free of charge to advanced tubcrculosis patients through township health workers although not sufficient in amounts. The number of patients the Health Center can care for is quite limited, so "drugs no longer given" and "recovered" means that these patients were taken off rolls as having completed treatment, cured or not.

According to subjective experience at the Koje Project through clinic observation or follow-up services, the reasons patients give for not returning seem mostly to be short of money, transportation difficult and not ill. where money is the most frequent reason. It was reported in a socioeconomical survey ${ }^{(9)}$ in Seoul that about one third defaulted due to economic reason and one fifth because they were too busy and not ill.

Through this survey and clinical experience in Koje Island, it is thought that there is several defaulting reasons, but that tuberculosis patients don't have enough information about their disease and its nature, treatment and prevention. As for the money, as it will be explained later, most patients will pay for treatment if they understand and convinced that tuberculosis can be cured within 1 to 2 years with adequate treatment.

\section{Institution where first diagnosed}

This question was asked to determine whether
Table 6. Defaulting Reason

\begin{tabular}{|c|c|c|}
\hline Defaulting Reason & $\begin{array}{c}\text { Koje Project } \\
(\%)\end{array}$ & $\begin{array}{l}\text { Health } \\
\text { Center }(\%)\end{array}$ \\
\hline Treating Elsewhore & 17 & 16 \\
\hline Not Ill & 6 & 8 \\
\hline Too Expensive & 25 & 3 \\
\hline Too Busy & 6 & 1 \\
\hline Too Far & 6 & 1 \\
\hline Treatment Not Good & 6 & 9 \\
\hline Misdiagnosis & 3 & 1 \\
\hline Recovered $\left.{ }^{1}\right)$ & 2 & 17 \\
\hline Unknown & 8 & 6 \\
\hline $\begin{array}{l}\text { Drugs No Longer } \\
\text { Given }\end{array}$ & - & 18 \\
\hline Others, No Response & 22 & 21 \\
\hline
\end{tabular}

1) Sometimes patients are told that they are not ill anymore without confirmed diagnosis at Health Center.

2) Drugs are not distributed by tuberculosis health workers if Government's drug supply is short.

tuberculosis patients get treatment continously at the same institution. By and large, many people tend to go to another clinics or institutions to confirm their disease. So some of defaulters in one clinic may be registered at another institution.

Among Koje Project-registered defaulters, about $60 \%$ were diagnosed at the Project. But only $49 \%$ were diagnosed first at the Koje Project who live in Hachung (home township of the project) and $33 \%$ were diagnosed at the mainland.

Among Koje Health Center-registered defaulters, about 70\% were diagnosed first at Koje

Table 7. Institution Where First Diagnosed by Myun

\begin{tabular}{|c|c|c|c|c|c|c|c|c|c|c|c|c|}
\hline \multirow[b]{2}{*}{ Diagnosed Institution } & \multicolumn{6}{|c|}{ Koje Project } & \multicolumn{6}{|c|}{ Health Center } \\
\hline & $\begin{array}{l}\text { Hach- } \\
\text { ung } \\
(\%)\end{array}$ & $\begin{array}{l}\text { Yon- } \\
\text { cho } \\
(\%)\end{array}$ & $\begin{array}{l}\text { Cha- } \\
\text { ng- } \\
\text { mok } \\
(\%)\end{array}$ & $\begin{array}{l}\text { Shin- } \\
\text { hyun } \\
(\%)\end{array}$ & $\mid \begin{array}{c}\text { Cha- } \\
\text { ngse- } \\
\text { ungpo } \\
(\%)\end{array}$ & $\begin{array}{l}\text { Tota } \\
(\%)\end{array}$ & $\mid \begin{array}{l}\text { Hach- } \\
\operatorname{ung} \\
(\%)\end{array}$ & $\begin{array}{c}\text { Yon- } \\
\text { cho } \\
(\%)\end{array}$ & $\begin{array}{l}\text { Cha- } \\
\text { ng- } \\
\text { mok } \\
(\%)\end{array}$ & $\begin{array}{c}\text { Shin } \\
\text { hyun } \\
(\%)\end{array}$ & $\mid \begin{array}{c}\text { Cha- } \\
\text { ngse- } \\
\text { ungpo } \\
(\%)\end{array}$ & $\begin{array}{c}\text { Total } \\
(\%)\end{array}$ \\
\hline Koje Project & 49 & 79 & 78 & 75 & 55 & 63 & 7 & 2 & & 3 & 11 & 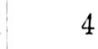 \\
\hline Health Center & 12 & 11 & 11 & 25 & 18 & 14 & 69 & 78 & 57 & 82 & 54 & 69 \\
\hline Other Clinics in Koje & 6 & 5 & 11 & & & 3 & 3 & 5 & 6 & 6 & 11 & 5 \\
\hline Mainland & 33 & 5 & & & 23 & 15 & 21 & 12 & 37 & 13 & 22 & 20 \\
\hline Don't Know & & & & & 5 & 5 & 3 & 2 & & & 3 & 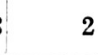 \\
\hline No. of People & 33 & 19 & 18 & 4 & 22 & 9 & 28 & 41 & 35 & 40 & 37 & 182 \\
\hline
\end{tabular}


Health Center. Of those who live in Shinhyun (where the Health Center is) $82 \%$ were diagnosed there first, a pretty high rate. The percentages diagnosed first at Health Center rank Shinhyun, Yoncho, Hachung and Changmok townships in order which is also the the rank order of remoteness from the Health Center. Considering that only about $50 \%$ of Seoul Health Center patients were diagnosed first at that Health Center, ${ }^{9,10)}$ higher percentages are consistently using the Government Health Center in Koje island than in Seoul.

\section{Name of first diagnosed disease and treatment}

In order to know how much defaulters understand of their disease, interviewees were asked to name their disease. Since less educated people still to some extent think that they would be confined in sanatoria if they become known to have tuberculosis. So physicians don't like to name tuberculosis directly but say instead that one's lungs are a little bad.

About $80 \%$ of Health Center-registered defaulters knew that their disease is tuberculosis or "pulmonary disease"(usually in Korea pulmonary tuberculosis is called "pulmonary disease"), however, only $66 \%$ among the Koje Project-reg istered defaulters admitted they knew their disease as tuberculosis or pulmonary disease. There were $17 \%$ naming another disease at the Project. But we must consider that $10 \%$ of Project tuberculosis is of non-respiratory systems, and that the patient may think of tuberculosis of other system as another disease.

What drugs were prescribed at the institution

Table 8. Name of First Diagnosed Disease

\begin{tabular}{l|c|c}
\hline \hline & $\begin{array}{c}\text { Koje Project } \\
(\%)\end{array}$ & $\begin{array}{c}\text { Health } \\
\text { Center(\%) }\end{array}$ \\
\hline Tuberculosis & 44 & 41 \\
Pulmonary Disease & 22 & 38 \\
Not Heard & 6 & 4 \\
Other Disease & 17 & 6 \\
Don't Know & 11 & 11 \\
\hline No. of People & $\mathbf{9 6}$ & $\mathbf{1 8 2}$ \\
\hline
\end{tabular}

of first diagnosis was questioned. Among Koje Project-registered defaulters, the triple regimen (INH, PAS and Streptomycin) was named most, and both triple regimen and two drug regimen (INH and PAS) together account for 50\%. One third of the defaulters did not know what drugs were prescribed, however, some of them remembered that $3 \mathrm{tab} / \mathrm{day}, 20 \mathrm{tab} / \mathrm{day}$ or a certain injecction was ordered. As we may have sup. posed, INH is the most frequently (35\%) prescribed drug at the Health Center.

Table 9. Prescribed Drug

\begin{tabular}{l|r|r}
\hline \hline & $\begin{array}{r}\text { Koje Project } \\
(\%)\end{array}$ & $\begin{array}{c}\text { Health Center } \\
(\%)\end{array}$ \\
\hline INH & 6 & 35 \\
SM & 1 & \\
PAS & 1 & 4 \\
INH +PAS & 21 & 13 \\
INH +PAS+SM & 28 & 14 \\
INH or PAS+SM & 3 & 10 \\
Nothing & 6 & 3 \\
Other Drugs & & 1 \\
Don't Know & 33 & 19 \\
\hline No. of People & $\mathbf{9 6}$ & $\mathbf{1 8 2}$ \\
\hline
\end{tabular}

The recommended period for taking the prescribed medicine was asked, and varied in percentage. Half of the defaulters, both at the Project and the Health Center, said that they did not hear a recommended period for taking. medicine. Surprisingly and regrettably, very

Table 10. Recommended Period of Taking Prescribed Medicine

\begin{tabular}{l|r|r}
\hline & $\begin{array}{r}\text { Koje Project } \\
(\%)\end{array}$ & $\begin{array}{c}\text { Health Center } \\
(\%)\end{array}$ \\
\hline Didn't tell & 48 & 48 \\
1-3 mo. & 6 & 2 \\
$4-6$ mo. & 16 & 6 \\
$7-9$ mo. & 2 & \\
10-12 mo. & 7 & 8 \\
13-18 mo. & & 1 \\
19-24 mo. & 1 & 3 \\
$25+$ mo. & 6 & 2 \\
Don't know & 13 & 30 \\
\hline No. of People & $\mathbf{9 6}$ & $\mathbf{8 2}$ \\
\hline
\end{tabular}


결핵 및 호흡기질환 Vol. 19, No. 4, Oct. 1972

few among interviewees knew that tuberculosis medication must be taken for more than a year.

\section{Knowledge of tuberculosis}

Three categories of questions were asked to determine knowledge of tuberculosis: relative knowledge about tuberculosis vs. other dread disease, knowledge of the consequences of tuberculosis and knowledge of the transmission of tuberculosis.

\section{Relative knowledge of tuberculosis vs. other dread diseases}

Several discases were arbitrarily chosen which rural people might think of as dreadful. In order to analyse relative dread, a score was made: tuberculosis is more dreadful, “ +1 ", about same and don't know, "0", and tuberculosis is less dreadful, "-1".

A higher score means that tuberculosis was said to be more dreadful than the reference disease. A negative score indicates that the reference disease was said to be more dreadful.

The descending sequence of scores is shown below.

The sequence of these "dread" scores in both institutions, is the same except for one place reverse between pertussis and measles on one end and between poliomyelitis and leprosy on the other.

A Health Interest Survey done by the Chung- nam Provincial Government and WHO Team ${ }^{(12)}$ in 1964 reported that tuberculosis is the most disliked disease with leprosy and typhoid next in order. The pattern is quite similar in this study.

Regarding measies and pertussis, infants and children are commonly infected. For example, there is an old saying in Korea that if man does not catch it during his life, he would catch measles in the grave. So, even though measles and pertussis claim a high fatality rate among infants and children, its inevitability in childhood and infancy and its low incidence in an adult population minimize fear.

Table 12. Descending Sequence of Scores

\begin{tabular}{|c|c|c|c|c|}
\hline \multirow{2}{*}{$\begin{array}{l}\text { Sequ- } \\
\text { ence }\end{array}$} & \multicolumn{2}{|l|}{ Koje Project } & \multicolumn{2}{|c|}{ Health Center } \\
\hline & Disease Sco & & Disease $\mathrm{S}$ & Score \\
\hline 1 & *Measles & \multicolumn{2}{|c|}{$+46 *$ Pertussis } & +5 \\
\hline 2 & *Pertussis & \multicolumn{2}{|c|}{$+44 *$ Measles } & +53 \\
\hline 3 & Neuralgia & +38 & \multirow{2}{*}{$\begin{array}{l}\text { Neuralgia } \\
\text { Fracture of } \\
\text { Arm }\end{array}$} & +50 \\
\hline 4 & Fracture of & +27 & & +37 \\
\hline 5 & Febrile Disease & +24 & Febrile Dis. & +21 \\
\hline 6 & Arthralgia & +18 & Arthralgia & +10 \\
\hline 7 & *Leprosy & +11 & *Poliomyelitis & +7 \\
\hline 8 & *Poliomyelitis & -2 & Leprosy & +3 \\
\hline
\end{tabular}

2. Knowledge ỗ the consequences of tuberculosis

There is little difference between Koje Project and Health Center defaulters in the knowledge

Table 11. Relative Knowledge of Tuberculosis vs. Other Dread Diseases

\begin{tabular}{|c|c|c|c|c|c|c|c|c|}
\hline & \multicolumn{4}{|c|}{ Koje Project } & \multicolumn{4}{|c|}{ Health Center } \\
\hline & $\begin{array}{c}\text { TB is } \\
\text { more } \\
\text { dreadful } \\
(\%)\end{array}$ & $\begin{array}{l}\text { About } \\
\text { same } \\
(\%)\end{array}$ & $\begin{array}{c}\mathrm{TB} \text { is } \\
\text { less } \\
\text { dreadful } \\
(\%)\end{array}$ & $\begin{array}{l}\text { Don't } \\
\text { know } \\
(\%)\end{array}$ & $\begin{array}{c}\text { TH is } \\
\text { morc } \\
\text { dreadful } \\
(\%) \\
\end{array}$ & $\begin{array}{l}\text { About } \\
\text { same } \\
(\%)\end{array}$ & $\begin{array}{c}\mathrm{TB} \text { is } \\
\text { less } \\
\text { dreadful } \\
(\%)\end{array}$ & $\begin{array}{l}\text { Don't } \\
\text { Know } \\
(\%)\end{array}$ \\
\hline Leprosy & 40 & 10 & 29 & 20 & 35 & 18 & 32 & 15 \\
\hline Febrile Disease & 47 & 7 & 23 & 23 & 48 & 10 & 27 & 15 \\
\hline Arthralgia & 43 & 8 & 25 & 24 & 34 & 18 & 24 & 24 \\
\hline Poliomyelitis & 30 & 17 & 32 & 20 & 37 & 12 & 30 & 20 \\
\hline Pertussis & 58 & 10 & 14 & 18 & 66 & 12 & 8 & 14 \\
\hline Fracture of Arm & 51 & 6 & 24 & 19 & 57 & 5 & 20 & 18 \\
\hline Measles & 62 & 1 & 16 & 22 & 66 & 5 & 13 & 15 \\
\hline Neuralgia & 59 & 3 & 21 & 17 & 68 & 6 & 12 & 15 \\
\hline
\end{tabular}


of the consequences of tuberculosis, except that a higher proportion of Health Center patients said tuberculosis causes "discomfort" and is "debilitating". We may suppose that among the Koje Project defaulters that minimal and moderate cases are predominant, while proportionally more sputum positive or advanced cases are registered at the Health Center.

3. Knowledge of the method of transmission of tuberculosis

"Yes" is the correct answer in items c, d and $\mathrm{g}$ in Table 14, while, "No" is correct in items $a, b$, e and $f$. The average correct answer score is $52 \%$ among Koje Project-reg istered defaulters, while $54 \%$ is average among Health Centerregistered defaulters, and the average number of "Don't know" responses for each of the $7^{\text {" }}$ items was $16 \%$ and $12 \%$ respectively. According to a study(9) less than $60 \%$ of Health Center patients understood the source of transmission.

It is surprising that interviewees would have so littler correct information about one of the: most dread diseases in the country.

\section{Present treatment}

Half of those who defaulted from the Koje Project were taking medicine elsewhere at the time of the survey. Only one third of defaulters. from Health Center treatment were taking. medicine elsewhere.

More than two thirds of Koje Project defaulters who continued treatment elsewhere were taking double or triple regimens, however, two thirds of the Health Centers defaulters taking:

Table 13. Knowledge of the Consequences of Tuberculosis (\%)

\begin{tabular}{l|c|c|c|c|c|c|}
\hline & \multicolumn{3}{|c|}{ Koje Project } & \multicolumn{3}{|c|}{ Health Center } \\
\cline { 2 - 7 } & Yes(\%) & No(\%) & $\begin{array}{c}\text { Don't Know } \\
(\%)\end{array}$ & Yes(\%) & No(\%) & $\begin{array}{c}\text { Don't Know } \\
(\%)\end{array}$ \\
\hline Can cause death & 46 & 46 & 8 & 41 & 55 & 4 \\
Painful & 22 & 69 & 9 & 18 & 76 & 6 \\
Causes discomfort & 58 & 32 & 9 & 78 & 18 & 4 \\
Debilitating & 52 & 42 & 6 & 67 & 29 & 4 \\
Agonizing & 66 & 26 & 8 & 75 & 19 & 6 \\
Can not be treated & 8 & 82 & 9 & 8 & 86 & 6 \\
\hline
\end{tabular}

Table 14. Knowledge of the Method of Transmission of Tuberculosis

\begin{tabular}{l|r|r|r|r|r|r}
\hline \hline & \multicolumn{3}{|c|}{ Koje Project } & \multicolumn{3}{|c}{ Health Center } \\
\cline { 2 - 7 } & Yes(\%) & No(\%) & $\begin{array}{r}\text { Don't Know } \\
\text { (\%) }\end{array}$ & Yes(\%) & No(\%) & $\begin{array}{c}\text { Don't know } \\
(\%)\end{array}$ \\
\hline a) Through taking the & 52 & 31 & 17 & 61 & 2 & 14 \\
b) Through using the & 49 & 34 & 17 & 60 & 29 & 12 \\
$\begin{array}{l}\text { patient's utensil } \\
\text { c) Through cough }\end{array}$ & 65 & 21 & 15 & 71 & 17 & 12 \\
d) Through spitted sputum & 58 & 26 & 16 & 64 & 24 & 12 \\
e) Through drinking & 39 & 43 & 18 & 40 & 42 & 18 \\
contaminated water & 19 & 62 & 20 & 19 & 69 & 13 \\
f) Congenitally & 74 & 17 & 9 & 81 & 13 & 6 \\
g) Infected to family & & & & &
\end{tabular}


treatment clsewhere were getting only INH.

In any case, about $40 \%$ of Project defaulters and $60 \%$ of Health Center defaulters were not taking any medicine at all.

Table 15. Medicine Taking Now

\begin{tabular}{l|r|r}
\hline \hline & $\begin{array}{c}\text { Koje Project } \\
(\%)\end{array}$ & $\begin{array}{c}\text { Health } \\
\text { Center(\%) }\end{array}$ \\
\hline INH & 9 & 20 \\
PAS & 5 & 1 \\
SM & 1 & 1 \\
INH +PAS & 20 & 9 \\
INH +PAS +SM & 18 & 1 \\
INH or PAS +SM & 1 & 1 \\
Nothing & 42 & 62 \\
No Response, Don't & 5 & 6 \\
Know & - & $\mathbf{1 8 2}$ \\
\hline No. of People & 96 & \\
\hline
\end{tabular}

\section{Ability to pay for the treatment monthly}

The question "How much could you pay a month for cure over one to two years?" was asked.

Fifty percent of Koje Project-registered defaulters replied that they could pay 500 Won $(400$ Won $=\$ 1$, June 1972) or more. The average was 571 Won including those who said they could pay nothing. Thirty seven percent of Health Center-registered defaulters replied that they could pay 500 Won or more, and the average was 491 Won.

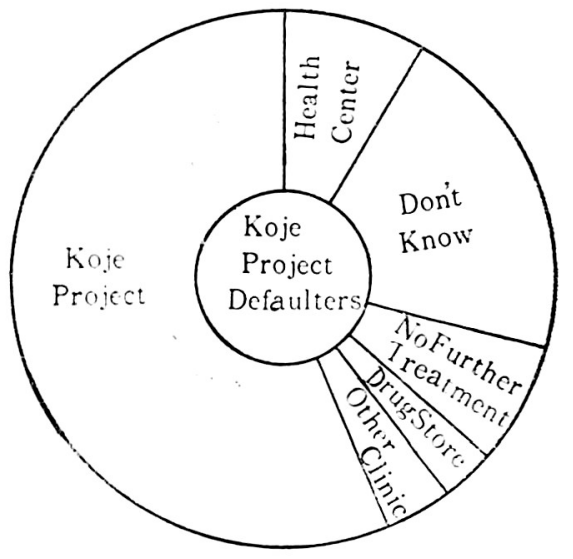

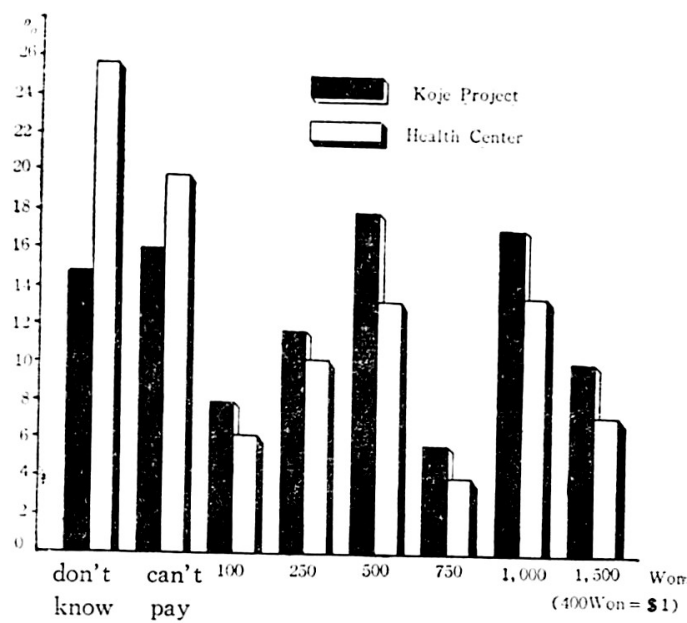

\section{Graph 1. Ability to Pay for the Treatment by} Month

The actual cost at Koje Project for two years of a triple drug regimen, including good physician care, X-ray every 6 months, sputum tests every 3 months, $2 \mathrm{X}$-rays for famliy contacts, and $P P D$ and $B C G$ vaccination for all children in the family is 20,000 Won. As a first course, no other regimen is better even including hospitalization (Madras study(14) Therefore the cost per month is olny 800 Won (standard drugstore prices are only slightly higher), which includes $X$-ray and $B C G$ vaccination for family contacts.

Double therapy, which is almost as efficacious, including complete tuberculosis family scrvice,

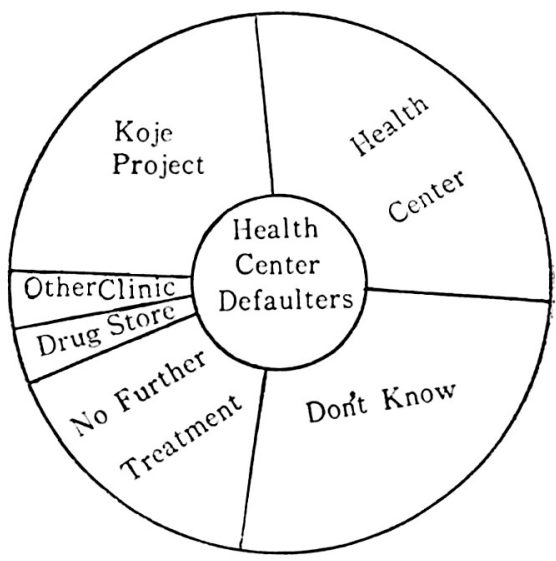

Graph 2. Patients Further Treatment Plans 
would cost only 16,000 Won or 670 Won a month.

Therefore, the rural economy can very neatly pay for complete tuberculosis care, especially if government drugs were separately obtained at the Health Centers.

Comparing costs, tuberculosis is no more expensive than an appendectomy, and considerably less expensive than illnesses treated with good in-patient care.

\section{Further treatment plan}

Seventy percent of Koje Project and 60\% of Health Center-registered defaulters claimed they would continue treatment. All were urged to continue by the survey team. (Graph 2)

\section{Conclusion}

Tremendous efforts have been made on tuberculosis control since the national tuberculosis control program was initiated. Mass screening, improvement of diagnostic skills, clinical efforts for better chemotherapy, and free distribution of tuberculosis drugs through Gavernment Health Centers have all been instituted. Such kinds of endeavor have, of course, played an important role in the tuberculosis control program.

However, if patients do not have sufficient knowledge about disease transmission, how long medicine has to be taken, and how to be treated optimally, control of tuberculosis will be much less effective and much more difficult.

Through this survey, it was recognized that more than half of the registered patients were not receiving optimal treatment, though no one reason for defaulting was significant. Lack of a sympathetic attitude at treatment institutuions and the failure to provide adequate information may account for the knowledge of tuberculosis being poor as expected. However, the ability to pay for treatment, as revealed by the survey, was higher than expected. Therefore the survey served a dual purpose: to research defaulters' knowledge and attitude, and to home visit, educate, and motivate proper tuberculosis treatment.

「The facts that people dread tuberculosis and are misinformed about tuberculosis have such a poor record of staying on treatment long enough to realize what should be a $90 \%$ or higher reccvery rate. The authors suggest that people

1) dread tuberculosis,

2) have misinformation and lack good information on tuberculosis,

3) have a very poor record for continuing treatment long enough to realize what could be a $90 \%$ or higher cure rate,

4) have enough money to pay for the best tuberculosis treatment, especially with Health Center aid, and

5) medicine and physicians are widely available all over the country.

It would seem to the authors that a tuberculosis information campaign is needed more than sny other single measure.

\section{References}

1. Ministry of Health \& Social Affairs. The Korean Institute of Tuberculosis, KNTA: Report on the Second Tuberculosis Prevalence Survey in Korea. Tuberculosis and Respiratory Diseases 18:4, Oct. 1971.

2. Johnson KG et al: 1971 Outpatient Clinic Data Report. Koje Health Reports Vol. 1, June 1972.

3. Song DH: Chemotherapy at Health Center. Tuberculosis and Respiratory Diseases 18:3, July 1971.

4. Sibley JR: Koje Community Health Project. Koje Health Reports Vol.1, June 1972.

5. Park HJ, Kang KW, Bang KM, Hong JW and Park SY: Epidemiological Study of Pulmonary Tuberculosis Patients Registered at Urban Health Centers. Tuberculosis Patients Registered at Urban Health Centers. Tuberculosis and Respiratory Diseases 18:2, Apr. 
1971.

6. Kim KH, Byon HW, Song DH, Lec CC, Kil BW, Pak JW, Jung NC and Bang KM: Report of Survey on Treatment Results of Patients at Health Centers. Tuberculosis and Respiratory Disease 16:3, July 1969.

7. Pak JW: Long-term Observation of Bacteriologically Positive Cases among Tuberculosis Patients Registered at Urban and Rural Health Centers. Tuberculosis and Respiratory Diseases $18:$, Jan. 1971.

8. Lee CS: The Outcome of Initially Diagnosed Pulmonary Tuberculosis Patients seen at Tuberculosis Specialst's Private Clinic. Tuberculosis and Respiratory Diseases $17: 3$, July 1970.

9. Kim TK: A Sociomedical Survey on Pulmonary Tuberculosis Patients Discontinued Chemotherapy. Tuberculosis and Respiratory Diseases Vol. 22, Jan. 1966.

10. Bang KM: A Sociomedical Survey on Pul-
결핵 및 호홉기질환 Vol. 19. No. 4, Oct. 1972 monary Tuberculosis Cases Newly Diagnosed. Tuberculosis and Respiratory Diseases Vol. 22, Jan. 1966.

11. Research Department of Cooperative Education Institutc: Survey Report in Preparation for Koje Community Health and Development Project. July, 1969.

12. Office of Rural Development in Chungnam Province and the Government/WHO Team on Local Health Services: Health Interest Survey. March 1964.

13. Johnson KG, Sibley JR, Kim $\mathrm{CN}$ and Kim IS: Koje Island Illness and Health Care Patterns. Yonsei Med. J. 11:2, 1970.

14. Dawson JJ, Devadatta S, Fox W et al: A 5-year Study of Patients with Pulmonary Tuberculosis in a Concurrent Comparison of Home and Sanatorium Treatment for one year with Isoniazid plus PAS. Bull. Wld Hlth Org. 34, 533, 1966.

\section{유신 파업 이룩하여}

\section{민주 주의 토착하자}

